Article

\title{
Satisfaction Factors That Predict Loyalty in Ecotourism: A Study of Foreign Tourism in Costa Rica
}

\author{
Mauricio Carvache-Franco ${ }^{1}\left[\right.$, Wilmer Carvache-Franco ${ }^{2, *}{ }^{\mathbb{D}}$, Allan Pérez-Orozco $^{3}$, \\ Ana Gabriela Víquez-Paniagua ${ }^{3}{ }^{(1)}$ and Orly Carvache-Franco ${ }^{4}$ \\ 1 Facultad de Turismo y Hotelería, Universidad Espíritu Santo, Samborondón 092301, Ecuador; \\ silcarfr@alumni.upv.es \\ 2 Facultad de Ciencias Sociales y Humanísticas, Escuela Superior Politécnica del Litoral, \\ Guayaquil 09015863, Ecuador \\ 3 Escuela de Administración de Empresas, Instituto Tecnológico de Costa Rica, Cartago 1597050, Costa Rica; \\ aperez@itcr.ac.cr (A.P.-O.); aviquez@itcr.ac.cr (A.G.V.-P.) \\ 4 Facultad de Especialidades Empresariales, Universidad Católica de Santiago de Guayaquil, \\ Guayaquil 090615, Ecuador; a20147142@pucp.pe \\ * Correspondence: wcarvach@espol.edu.ec; Tel.: +593-980-105-090
}

check for updates

Citation: Carvache-Franco, M.; Carvache-Franco, W.; Pérez-Orozco,

A.; Víquez-Paniagua, A.G.;

Carvache-Franco, O. Satisfaction

Factors That Predict Loyalty in Ecotourism: A Study of Foreign Tourism in Costa Rica. Land 2022, 11, 125. https://doi.org/10.3390/

land11010125

Academic Editors: Antonio Rafael Peña-Sánchez, Luis Pires Jiménez, Carmen Lizarraga and José Ruiz Chico

Received: 10 December 2021

Accepted: 10 January 2022

Published: 13 January 2022

Publisher's Note: MDPI stays neutral with regard to jurisdictional claims in published maps and institutional affiliations.

Copyright: (C) 2022 by the authors. Licensee MDPI, Basel, Switzerland. This article is an open access article distributed under the terms and conditions of the Creative Commons Attribution (CC BY) license (https:// creativecommons.org/licenses/by/ $4.0 /)$.

\begin{abstract}
Recently, foreign tourists have revealed a growing interest for natural environment enjoyment. This study aimed to: (a) identify the service satisfaction factors and (b) analyze the influence that satisfaction factors exert on the loyalty of ecotourists. The empirical analysis was carried out in Arenal National Park and Caño Negro Wildlife Refuge in Costa Rica, a country with international prominence in ecotourism due to the wealth of resources in its protected areas. A factorial analysis and the stepwise multiple regression method were performed for the data analysis of 246 surveys made in situ. Results show three satisfaction factors in ecotourism: "nature and culture", "infrastructure", and "service", where "nature and culture" was the most influential predictor of tourists" loyalty. The study also found a positive correlation between satisfaction and loyalty in ecotourism. This research will provide relevant insights to public institutions and private companies efficient planning and benefit the community and protected areas.
\end{abstract}

Keywords: satisfaction; loyalty; ecotourism; foreign tourist; Costa Rica

\section{Introduction}

Visitor satisfaction is a vital aspect of national park marketing and management practice [1,2]. Therefore, understanding the importance of satisfaction allows managers to provide facilities and services according to the expectations of visitors [3-5]. In this sense, ecotourists tend to show significant levels of perceived satisfaction with the experiences lived during an ecotourism visit [6-9]. In addition, marketing approaches, which consider tourism satisfaction and behavioral intentions, remain an essential area for research in tourism studies [10].

Ecotourism includes contact with nature, culture, agriculture, wildlife, and adventure activities [11]. Ecotourism areas have become important destinations due to their efficiency in protecting the environment and supporting education, recreation, and job creation [12]. The growing popularity of ecotourism around the world has encouraged tourist destinations to receive more and more tourists who like contact with nature and are willing to comply with the protection regulations of the chosen natural space [13]. Ecotourists search for nature and culture in a national park with their family and friends [14]. Managers must realize the economic importance of meeting the needs of visitors and providing them with memorable experiences [15]. Hence, satisfaction is often an important goal that park managers seek to achieve [5]. Likewise, mega faunas and impressive ecosystems are attributes of satisfaction in ecotourism [16-18]. Most protected area studies evaluate the essential 
attributes of a site, such as boats or trails, and identify high levels of visitor satisfaction [15] Despite the referred context, research on destinations related to nature has been neglected in the literature [19]. For Rahman et al. [20], community participation explains a significant amount of variation in the development of ecotourism. The findings reveal that the development of ecotourism contributes to economic, social, and environmental sustainability directly and indirectly.

Inbound tourism encompasses the activities carried out by a non-resident visitor in the country of reference as part of an inbound tourist trip World Tourism Organization UNWTO [21]. In this sense, foreign tourists play an important role in national economies [22]. Therefore, the entry of foreign tourists to countries can play an effective role in increasing income exchange, creating new and more employment opportunities and fertilizing the tourism industry, and consequently, can promote quality of life and accelerate the country's development process [23].

Satisfaction factors are vital studies around the world, because the study of satisfaction in foreign tourists is an important indicator to analyze the return of foreign tourists, an important indicator in national economies. This study will contribute to the literature by finding the satisfaction factors that most influence the loyalty variables, results that are not found in the academic literature.

Within this framework, Costa Rica is an ecotourism country of international relevance and abundant protected natural areas. Arenal Volcano National Park is an icon of the nature of this country. This protected area is an important living laboratory for its geological and geomorphological richness and its great complexity in the development of biological processes. Another protected area is Caño Negro National Wildlife Refuge, a wetland where a large number of endangered species, migratory birds, mammals, and endemic freshwater fish can be observed.

This article aims to: (a) identify service satisfaction factors and (b) analyze the influence that satisfaction factors have on tourists' loyalty. The theoretical relevance of this study relies on the analysis of the different relationships between service features and tourist loyalty. For this, the present study asks the following research questions:

RQ1: What is the service satisfaction factors in ecotourism?

RQ2: What are the service factors that predict loyalty in ecotourism?

Then, the study raises the following hypothesis:

Hypothesis 1 (H1). There is a positive correlation between general satisfaction and the loyalty variables formed by the intentions to return, recommend, and say positive things in ecotourism.

Likewise, the study has a practical application, because it provides information on the satisfaction factors that positively influence the loyalty of visitors to tourismrelated companies.

\section{Literature Review}

For López-Sanz et al. [24], tourism is an activity that contributes directly and indirectly to the development of rural areas, but it is relevant that it be sustainable, which requires implementing adequate policies that positively affect these areas from an economic, social, and cultural point of view, since the above influences the behavior of the tourist, the motivation, the image of the destination, and the satisfaction that it has. For example, Henche et al. [25] have proposed novel management models for tourist cities based on creative tourism that involves the role of small business associations and collaboration networks between various actors to develop a historical cultural tourism ecosystem, in such a way that the support of the public and private sectors and models of sustainable governance is fostered.

Delving into loyalty and the sectors of the tourism ecosystem, López-Sanz et al. [26], in a recent study, demonstrate how loyalty, translated into repeated visits to a tourist area and the recommendation to third parties, promotes and encourages the sustainable 
development of rural areas, generating several benefits for the tourist destination. It should be emphasized that tourism in rural areas largely depends on the successful promotion of both its beautiful landscapes and its cultural heritage, as well as the development and improvement of the areas, factors that even raise the level of employment in the tourist destination [27].

Satisfaction refers to the positive feeling or pleasure obtained after experiencing or consuming a tourist product [28]. It is a psychological aspect and state of mind that arises after the tourist exposure to an environment [29]. Furthermore, satisfaction has been described as the cognitive-affective state resulting from a positive consumer experience [30]. Researchers have recognized that satisfaction depends on the products and prices offered, the quality of the services provided, and the friendly attitude of the local inhabitants [31]. In this regard, the levels of satisfaction experienced by visitors of a national park or a protected area can be indirectly measured through the stimuli they receive in that area and their contact with the natural characteristics of the protected area [32].

For tourism, the strong relationship between satisfaction and the behavior of future customers is essential. This means that a satisfied consumer will repeat the visit and communicate the positive aspects of the visit with other people [33,34]. In addition, satisfaction is the result of a general evaluation carried out by the vacationer after the purchase [35-37]. In this sense, satisfaction increases the probability that visitors will make a stopover at the destination again and recommend it to their friends and family [38,39]. Therefore, satisfaction is related to the choice of destination, the consumption of products and services, and the decision to return $[29,38,39]$. Several studies have shown that repeated visits to tourist destinations are related to higher levels of visitors' satisfaction, because satisfaction partly motivates them to return and visit the same destination [40-43]. In fact, satisfaction leads to repeat visits [44,45], to achieve visitor loyalty [46], and it is a powerful marketing tool that helps promote the tourist site and increase the frequency of visits $[47,48]$. According to several studies, satisfaction has a positive influence on post-purchase behavior [49-54]. In addition, several researchers have found a relationship between general satisfaction and satisfaction by attributes or aspects that provoke a return and recommendation of the site [55-62]. From the perspective of perceived value for Carvache-Franco et al. [63], all dimensions positively influence satisfaction and loyalty. The economic-functional dimension is the one that most influences satisfaction, while the emotional-social dimension is the most influential on loyalty.

Regarding the studies on ecotourism satisfaction, Tsiotsou and Vasioti [64] conducted research on tourist services in Greece and identified satisfaction factors that included "staff satisfaction", "satisfaction with food", "satisfaction with the excursion", "satisfaction with socialization", and "satisfaction with the landscape". In contrast, Meng et al. [65], in their study of satisfaction from nature-based resorts in southwestern Virginia, identified "quality/friendly services", "outdoor activities", "accommodation", and "natural landscapes" satisfaction factors. Lee [66] found the following satisfaction factors: "information services", "recreational facilities", and "safety and sustainability". Instead, Adam et al. [67] studied ecotourists' satisfaction in Kakum National Park using the following factors: "educational satisfaction", "social satisfaction", "satisfaction with sanitation", and "satisfaction with relaxation".

In a study carried out in the Gili Matra Marine Park (West Nusa Tenggara Province Indonesia), academics Chen et al. [68] argued that value orientation is a direct predictor of ecotourism satisfaction. Xu et al. [69], in a study carried out in Zhalong National Nature Reserve located in the west of Heilongjiang province (China), identified a high degree of satisfaction with the natural environment of the study area but a relatively low satisfaction with the biodiversity, facilities, and services of the scenic place. In a study of ecotourism in Malaysia, scholars Chan et al. [70] found that service quality has a significant and positive impact on satisfaction, while satisfaction was found to drive review intentions. Additionally, that the image of the destination has a significant positive impact on tourist satisfaction. Scholars Hwang and Lee [71] found significant relationships 
between ecological belief and willingness to pay for ecotourism services that influenced ecotourism behavior, and between ecological belief and ecotourism behavior that affected ecotourism behavior. Concerning satisfaction with life, Lee et al. [72] proposes that wildlife ecotourism programs should improve the quality of their interpretation services to increase thoughtful participation, thereby improving wildlife ecotourism behavior during wildlife tours and assisting in sustainable development. of wildlife ecotourism.

From another perspective, scholars Li et al. [73], in a study of Chinese ecotourists in Australia, identified that acting, fun learning, and emotional experiences influenced both the attribute-based and holistic image of the destination. Additionally, the tourism experience had an indirect effect on loyalty (including destination loyalty and ecotourism loyalty) through the mediating effects of destination image and satisfaction. Along the same lines, scholars Quynh et al. [74] analyzed Vietnamese tourists who had visited ecological destinations, and identified that the positive image of the destination and the different experiences are considered the main elements that promote positive emotions and satisfaction in tourists, leading to greater eagerness for spreading WOM recommendations and revisiting a destination.

In summary, there are several factors found in the different studies with a certain degree of similarity between them. The majority of these factors must be compared, especially those that are most similar in the different studies, in order to be able to compare and discuss them. These factors are related to nature, because they were found in studies carried out in natural sites or protected areas. The factors with the greatest similarity between the studies will be considered to compare them with the findings of this study.

\section{Study Area}

The researchers selected Arenal Volcano National Park and the Caño Negro National Wildlife Refuge protected areas in Costa Rica, whose biodiversity makes them important destinations for Ecotourism. In particular, the Arenal National Park is selected, because it is one of the parks with the most visits nationwide and it is considered a natural laboratory and the Caño Negro National Wildlife Refuge in Costa Rica, since its characteristics make it a wetland of international importance (Figure 1).

\subsection{Arenal National Volcano Park}

The park's extension is 12,124 hectares, and it is located in the Northern Region of Costa Rica, in the Guanacaste Volcanic Mountain Range, north of the Sierra de Tilarán and part of the San Carlos plains. The surface is irregular, from deep valleys with great slopes, cut by mighty rivers, to flat and undulating forms. It is considered an aquifer recharge zone, whose waters drain into the Arenal Reservoir for the production of hydroelectric energy and agricultural projects in the Moracia Irrigation District. The Chiquito, Peñas Blancas, and Frío Rivers are born in the site. The park protects relevant species of flora and fauna of premontane pluvial and cloud forests that have great scientific and tourist value.

\subsection{Caño Negro Natural Wildlife Refuge}

The refuge is located in the lower part of Frío River basin, in the Northern Plains, $21 \mathrm{~km}$ southwest of the community of Los Chiles and $36 \mathrm{~km}$ southeast of the community of Upala, whose cantons belong to Alajuela province. The reserve area transportation is by canoe or boat, depending on the weather. The refuge comprises 10,171 hectares, and it preserves one of the most important samples of humid areas in Costa Rica. The site has international relevance, because it is a shelter for many migratory, in danger of extinction, and commercial species. 

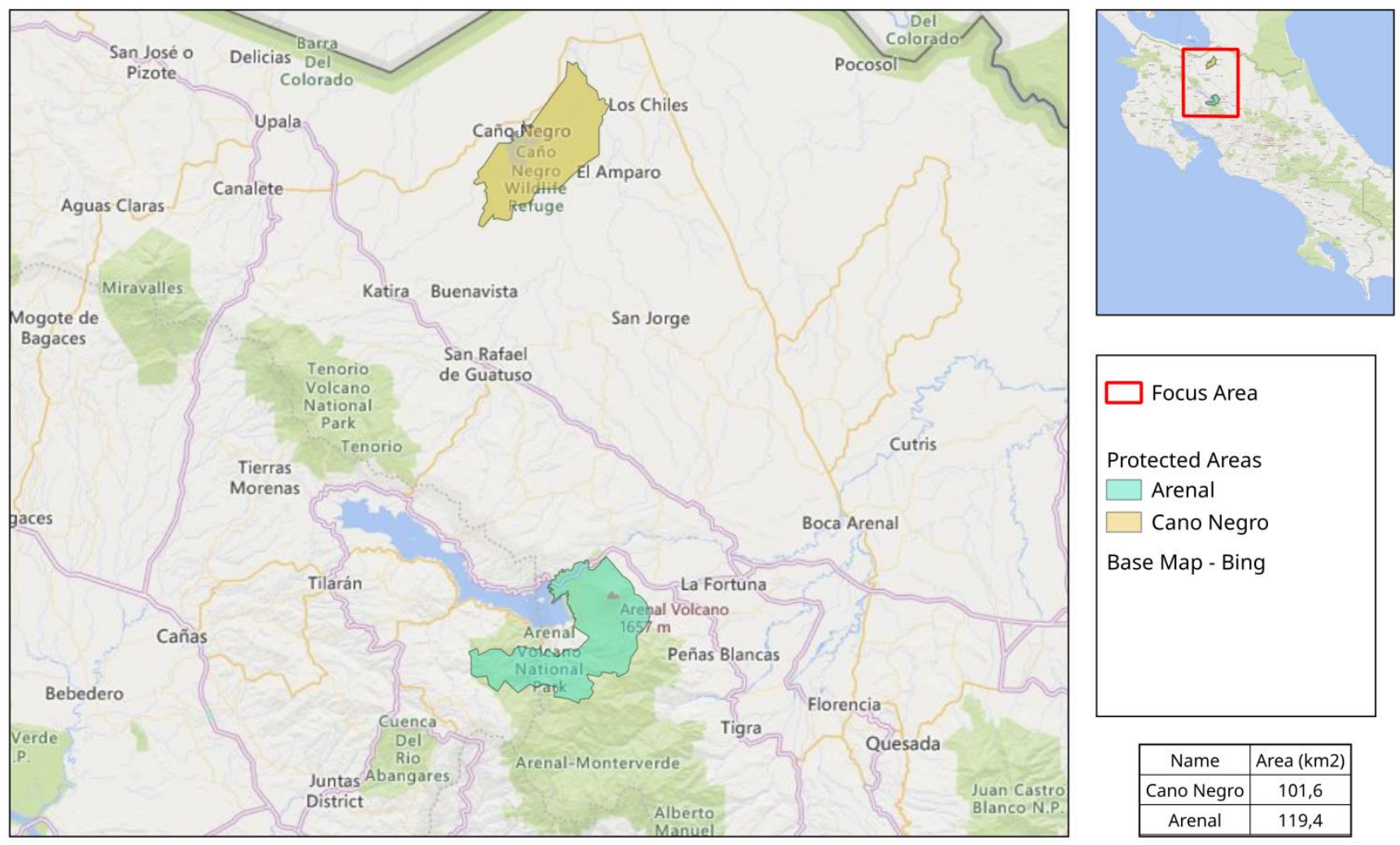

Focus Area

Protected Areas

$\square$ Arenal

Cano Negro

Base Map - Bing

$40 \mathrm{~km}$

Figure 1. The geographic location of protected areas: Arenal Volcano National Park and Caño Negro Mixed National Wildlife Refuge (Costa Rica).

\section{Methodology}

The sample consisted of foreign tourists visiting Arenal National Park and Caño Negro Wildlife Refuge. The questionnaire for this study was divided into two parts. The first part of the questionnaire measured the sociodemographic and visiting characteristics of the respondents. The second part of the questionnaire measured motivations, satisfaction variables by aspects, general satisfaction, and loyalty variables (intention to return, recommend, and to say positive things about the destination). Regarding motivations, a five-point Likert-type scale was used, where 1 was not important at all, and 5 was very important. In the case of satisfaction, a five-point Likert-type scale was used, where 1 was not at all satisfied, and 5 was very satisfied. Concerning return intentions, recommendation and providing positive feedback about the destination, a five-point Likert-type scale was used, where 1 was strongly disagree, and 5 was strongly agree. The measurement elements of the present study were based on ecotourism studies [75-80]. Cronbach's Alpha of satisfaction reached the value of 0.88 , which indicates a robust index for the scale.

The surveys were applied to foreign tourists who were within the protected area in March and April of 2019. The steps carried out in the fieldwork for this research are considered in the first instance surveying foreign tourists who are in the tourist destinations understudy with an age of 18 years or more. Convenience sampling was used according to the availability of tourists to answer the questionnaires. To confirm that the sample was similar to the population, the representativeness of the tourist population was taken into account. Thus, the surveys were carried out, in a considerable proportion, with the groups of tourists with the greatest presence in the destination.

The surveys were conducted while tourists were engaged in recreational, guided, or rest activities. The surveys were taken by students from the Tecnológico de Costa Rica, who 
were trained by the authors of this study to do fieldwork. The variability of the population was estimated at $50 \%(p=q=0.5)$. The sample size was 246 surveys, with a margin of error of $6.7+/-\%$ and a confidence level of $95 \%$, an appropriate sample size for causal studies. For the first stage of the data evaluation, the researchers applied a factor analysis to identify the constructs that underlie the variables and provide a global vision of the satisfaction factors. Factor analysis has been widely used in tourism research [81-83].

Specifically, in factor analysis, a Varimax rotation was used to facilitate the interpretation of the data. Moreover, the Kaiser criterion was used to find the number of factors, where only the factors with eigenvalues greater than 1 were used [84].

The Kaiser-Meyer-Olkin (KMO) index and the Bartlett sphericity test were used to determine if it was appropriate perform factor analysis [85].

In the second stage of the data analysis, the stepwise multiple regression method was implemented to find the most important predictors (satisfaction factors) in the loyalty variables: return intentions, intentions to recommend, and saying positive things about the protected areas. The collected data were organized, tabulated, and statistically analyzed using the SPSS 22.0 program for Windows.

\section{Results}

\subsection{Sociodemographic Profile of the Study Sample}

The sample of this study was composed of foreign tourists, to a sample that was representative of the study population, carrying out the study in the different sites within the protected areas, and at different dates and times. Of this sample, $43.5 \%$ were male, and $56.5 \%$ were female. Regarding its origin by continent, it was mainly European (46.3\%), followed by the North American group (40.7\%). Overall, 54.1\% were single, 33.3\% were married, and $12.6 \%$ had another type of relationship. The majority group was in the range between 21 and 30 years (39.8\%), followed by the group between 31 and 40 years $(21.1 \%)$. Regarding their level of studies, the vast majority had university degrees $(42.7 \%)$, followed by the group with postgraduate degrees $(33.3 \%)$. The tourists were mainly private employees $(26.4 \%)$, followed by students $(21.5 \%)$. The majority of foreign tourists were in Costa Rica for the first time (88.2\%). Tourists traveled mostly in pairs (33.7\%) and with relatives $(30.5 \%)$.

\subsection{Factor Analysis}

A factor analysis was used to find the satisfaction factors and their relationships with the loyalty variables. The factor analysis improved the interpretation of the results of satisfaction by aspect in the service. For data extraction, principal component analysis was used. Then, the Varimax rotation method ordered the factors, with high or low factor loads. To find the number of factors, the researchers applied the Kaiser criterion, where factors with eigenvalues greater than 1 were taken into account. Thus, four factors were identified, and they represented $62.21 \%$ of the total variance. The Cronbach's Alpha of the factors ranged from 0.83 to 0.75 that confirmed the consistency for the factor analysis. The factor loadings ranged from 0.50 to 0.83 , and all of them were within the critical value of 0.50 suggested by Hair [86]. The KMO index was 0.87 , indicating a significant relationship between the variables. In addition, the Barlett sphericity test was significant $\left(\chi^{2}=1380.969\right.$, $p=0.000)$. Hence, it was appropriate to perform the factor analysis. The results are shown in Table 1. 
Table 1. Factor analysis of service aspects.

\begin{tabular}{|c|c|c|c|}
\hline Variable & $\begin{array}{l}\text { Factor 1. Satisfaction with } \\
\text { the Infrastructure }\end{array}$ & $\begin{array}{c}\text { Factor } 2 . \\
\text { Satisfaction with Nature } \\
\text { and Culture }\end{array}$ & $\begin{array}{c}\text { Factor 3. Satisfaction } \\
\text { with Services }\end{array}$ \\
\hline Road signs & 0.831 & & \\
\hline Parking & 0.808 & & \\
\hline $\begin{array}{l}\text { Accessibility and } \\
\text { infrastructure }\end{array}$ & 0.703 & & \\
\hline Tourist information and signs & 0.568 & & \\
\hline Accommodation & 0.500 & & \\
\hline $\begin{array}{c}\text { Conservation of natural and } \\
\text { cultural heritage }\end{array}$ & & 0.828 & \\
\hline Calmness & & 0.810 & \\
\hline Locals' behavior with tourists & & 0.771 & \\
\hline $\begin{array}{c}\text { Restaurant } \\
\text { facilities/equipment }\end{array}$ & & & 0.694 \\
\hline Guided tours & & & 0.692 \\
\hline Gastronomy & & & 0.618 \\
\hline $\begin{array}{c}\text { Complimentary leisure } \\
\text { activities }\end{array}$ & & & 0.556 \\
\hline Prices & & & 0.554 \\
\hline Cronbach's $\alpha$ & 0.829 & 0.813 & 0.752 \\
\hline Eigenvalue & 5.560 & 1.525 & 1.002 \\
\hline Variance explained (\%) & 42.768 & 11.734 & 7.707 \\
\hline $\begin{array}{l}\text { Cumulative variance } \\
\text { explained (\%) }\end{array}$ & 42.768 & 54.502 & 62.208 \\
\hline
\end{tabular}

According to the results presented in Table 1, the "Infrastructure" satisfaction factor was related to aspects of the service such as signage, infrastructure, and accessibility. This factor included $42.77 \%$ of the total variance, making it the most outstanding factor. The "Nature and culture" satisfaction factor was related to aspects of the service such as the conservation of nature and culture, tranquility and locals' behavior with tourists. This factor represented $11.73 \%$ of the total variance. The "Services" satisfaction factor was related to aspects such as gastronomy services, guided tours, and other complementary leisure activities. This factor represented $7.71 \%$ of the total variance. The results answer our first research question:

RQ1: What is the service satisfaction factors in ecotourism?

The ecotourism satisfaction factors were infrastructure, nature and culture, and services.

\subsection{Relationship of Satisfaction Factors with Return Intentions}

To analyze the most important predictors in return intentions, the authors used a stepwise multiple regression, which included the satisfaction factors that were significant for the model. The results are presented in Table 2. 
Table 2. Relationship of satisfaction factors with return intentions (Multiple regression).

\begin{tabular}{ccccc}
\hline Satisfaction Factors & Beta & $\mathbf{t}$ & Sig. & Tolerance \\
\hline Nature and culture & 0.227 & 3.716 & 0.000 & 1.000 \\
\hline Infrastructure & 0.171 & 2.807 & 0.005 & 1.000 \\
\hline Services & 0.165 & 2.703 & 0.007 & 0.000 \\
\hline (Constant) $^{2}$ & & & \\
\hline Adj. R ${ }^{2}$ & 0.096 & & \\
\hline F statistic & 9.637 & & \\
\hline Sig. & 0.000 & & \\
\hline Durbin-Watson & 1.428 & & \\
\hline
\end{tabular}

According to Table 2, the three satisfaction factors seemed to predict return intentions. The $\mathrm{F}$ test was significant $(p<0.05)$, indicating a real relationship between significant predictors and return intentions. Furthermore, the tolerance values indicated that there was no multicollinearity between the independent variables. Likewise, the Durbin-Watson statistic reached a value of 1.43 , which suggests the absence of auto-correlation in the errors and confirms the suitability of the model. The satisfaction factor "Nature and culture" was the most significant predictor in return intentions (Beta $=0.227, p<0.05$ ), followed by the satisfaction factor "Infrastructure" (Beta $=0.171, p<0.05)$.

\subsection{Relationship of Satisfaction Factors with the Intentions to Recommend the Destination}

To analyze the most relevant predictors in the intentions of recommending the site, a stepwise multiple regression, which included the satisfaction factors that were significant for the model, was used. Table 3 summarizes the results.

Table 3. Relationship of satisfaction factors with the intentions to recommend the destination (Multiple regression).

\begin{tabular}{ccccc}
\hline Satisfaction Factors & Beta & $\mathbf{t}$ & Sig. & Tolerance \\
\hline Nature and culture & 0.367 & 6.782 & 0.000 & 1.000 \\
\hline Services & 0.341 & 6.303 & 0.000 & 1.000 \\
\hline Infrastructure & 0.209 & 3.863 & 0.000 & 0.000 \\
\hline (Constant) $^{2}$ & & & \\
\hline Adj. $\mathbf{R}^{2}$ & 0.286 & & \\
\hline F statistic & 33.552 & & \\
\hline Sig. & 0.000 & & \\
\hline Durbin-Watson & 1.585 & & \\
\hline
\end{tabular}

Table 3 presents the three satisfaction factors that predict intentions to recommend the destination. The F test was significant $(p<0.05)$, and it indicated a real relationship between the significant predictors and the intentions to recommend. The tolerance values showed that there was no multicollinearity between the independent variables. In addition, the Durbin-Watson statistic reached a value of 1.59, so it could be assumed that there was no auto-correlation in the errors and the appropriateness of the model. The factor "Nature and culture" was the most significant predictor in the intentions to recommend (Beta $=0.367$, $p<0.05$ ), followed by the factor "Services" (Beta $=0.341, p<0.05$ ). 


\subsection{Relationship of Satisfaction Factors with Saying Positive Things about the Destination}

To analyze the most important predictors in saying positive things about the destination, a multiple stepwise regression, which included the satisfaction factors that were significant for the model, was used. The results are presented in Table 4.

Table 4. Relationship of satisfaction factors and saying positive things about the destination.

\begin{tabular}{ccccc}
\hline Satisfaction Factors & Beta & T & Sig. & Tolerance \\
\hline Nature and culture & 0.358 & 6.605 & 0.000 & 1.000 \\
\hline Services & 0.352 & 6.481 & 0.000 & 1.000 \\
\hline Infrastructure & 0.195 & 3.602 & 0.000 & 0.000 \\
\hline (Constant) & & & & \\
\hline Adj. $\mathbf{R}^{2}$ & 0.282 & & & \\
\hline F statistic & 32.869 & & \\
\hline Sig. & 0.000 & & \\
\hline Durbin-Watson & 1.649 & & \\
\hline
\end{tabular}

Regarding Table 4, the three satisfaction factors seemed to predict saying positive things about the destination. The $\mathrm{F}$ test was significant $(p<0.05)$, and it indicated a real relationship between significant predictors and saying positive things about the destination. The tolerance values indicated that there was no multicollinearity between the independent variables. In addition, the Durbin-Watson statistic reached a value of 1.67, so it could be assumed that there was no auto-correlation in the errors, so the model was adequate. The factor "Nature and culture" was the most significant predictor in saying positive things about the destination (Beta $=0.358, p<0.05$ ), followed by the factor "Services" (Beta $=0.352$, $p<0.05)$.

These results answer our second research question:

RQ2: What are the service factors that predict loyalty in ecotourism?

The satisfaction factors "nature and culture" and "infrastructure" influenced return intentions, while the satisfaction factors "nature and culture" and "services" were those that influenced the intentions to recommend and say positive things.

\subsection{Relationship of General Satisfaction with the Loyalty Variables}

A multiple stepwise regression was used to analyze the relationship of general satisfaction with the loyalty variables. The results are presented in Table 5.

Table 5 shows that the $\mathrm{F}$ test was significant $(p<0.05)$ in the three models of general satisfaction with the variables of loyalty. Furthermore, the tolerance values in the three models indicated that there was no multicollinearity between the independent variables. Likewise, the Durbin-Watson statistic in the three models reached a value between 1.5 and 2.5, which suggests no identifiable relationship in the errors. Therefore, the three models were adequate. The general satisfaction variable presented a positive correlation with the intentions to return, intentions to recommend, and saying positive things about the destination.

Results that affirmatively verify our research hypothesis:

Hypothesis 1 (H1). There is a positive correlation between general satisfaction and the loyalty variables formed by the intentions to return, recommend, and say positive things in ecotourism.

The findings showing that there is a positive correlation between satisfaction and loyalty in ecotourism. 
Table 5. Relationship of general satisfaction with the loyalty variables.

\begin{tabular}{|c|c|c|c|c|c|c|c|c|c|}
\hline \multirow[t]{2}{*}{ Variable } & \multicolumn{3}{|c|}{ Return Intentions } & \multicolumn{3}{|c|}{ Recommendation Intentions } & \multicolumn{3}{|c|}{$\begin{array}{l}\text { Say Positive Things } \\
\text { about Destination }\end{array}$} \\
\hline & Beta & $\mathrm{T}$ & Sig. & Beta & $\mathbf{t}$ & Sig. & Beta & $t$ & Sig. \\
\hline $\begin{array}{l}\text { Overall } \\
\text { satisfac- } \\
\text { tion }\end{array}$ & 0.513 & 9.317 & 0.000 & 0.732 & 16.763 & 0.000 & 0.709 & 15.696 & 0.000 \\
\hline (Constant) & & -0.197 & 0.844 & & 2.487 & 0.014 & & 5.681 & 0.000 \\
\hline Adj. $\mathrm{R}^{2}$ & 0.260 & & & Adj. $R^{2}$ & 0.533 & & Adj. $R^{2}$ & 0.500 & \\
\hline F statistic & 86.799 & & & F statistic & 281.004 & & F statistic & 246.379 & \\
\hline Sig. & 0.000 & & & Sig. & 0.000 & & Sig. & 0.000 & \\
\hline $\begin{array}{l}\text { Durbin- } \\
\text { Watson }\end{array}$ & 86.799 & & & $\begin{array}{l}\text { Durbin- } \\
\text { Watson }\end{array}$ & 1.858 & & $\begin{array}{l}\text { Durbin- } \\
\text { Watson }\end{array}$ & 2.024 & \\
\hline Tolerance & 1.000 & & & Tolerance & 1.000 & & Tolerance & 1.000 & \\
\hline
\end{tabular}

\section{Discussion}

The objectives of this study were related to finding service satisfaction and its influence on tourist loyalty. Among the findings of this study, three satisfaction factors were found. The first satisfaction factor was "Nature and Culture", whose results were similar to the study by Tsiotsou and Va-sioti [64], who found the factor "satisfaction with the landscape". Another result related to nature was found in the study by Meng et al. [65], who found the satisfaction factor in "natural landscapes". Another study related to nature was that of Xu et al. [69], who identified "satisfaction with the natural environment". The second factor found in this study was "infrastructure." Infrastructure-related results were found in the study by Lee [66], who called it "recreational facilities", while "Service" was the third satisfaction factor in the present study, finding similar results with the service in the study by Tsiotsou and Vasioti [64], who found the factors "satisfaction with food" and "satisfaction with food excursion". Furthermore, similar results were found with the service in the study by Meng et al. [65], who called the factor "friendly services/quality". Another study related to service was that of Chan et al. [70], who found that the quality of the service has a significant and positive impact on satisfaction.

Furthermore, general satisfaction influenced the intentions to return to the destination; similar results arose in several studies [29,38,39,44,45,87]. In addition, general satisfaction affected the intentions to recommend the destination. These findings coincide with studies $[38,39]$. Likewise, satisfaction also influenced the intentions to say positive things about the destination, and analogous results were identified by scholars [33,34,88]. However, the satisfaction factors that influenced loyalty in ecotourism have not been addressed in the literature. Thus, the contributions of this study to the literature are the satisfaction factors "nature and culture" and "services", as these highly influenced the intentions to recommend and say positive things about the destination, whereas the satisfaction factor that highly influenced the return intentions were "nature and culture" and "infrastructure". These dimensions of service are important for tourists, and they should be maintained and improved to please tourists and encourage their return to a destination. Consequently, the destination will benefit from income and employment increase.

Among the theoretical implications, we have that there are three satisfaction factors: one of them is "nature and culture", similar to other authors [64,65,69]; one is "infrastructure", similar to other authors [66]; and a third factor is "service", similar to the findings of other authors $[64,65,70]$. On the other hand, there is a significant correlation between satisfaction and loyalty $[33,34,39,45,70]$. Among the contributions of this study are that the satisfaction factor "nature and culture" is the most influential in the loyalty of tourists in protected areas. The satisfaction factor "nature and culture" and the satisfaction factor "services" are the ones that greatly influence the intentions to recommend and the intentions to 
say positive things about the destination, while the satisfaction factors "nature and culture" and "infrastructure" are the ones that considerably influence the return of tourists.

\section{Conclusions}

In ecotourism, the study of satisfaction is essential for identifying the factors that deeply influence the loyalty of tourists. Hence, with proper planning, the service can be improved to achieve greater satisfaction and return of tourists. As a result, the destination and its community will benefit, with higher income and employment.

"Nature and culture", "infrastructure", and "service" are the three satisfaction factors found in ecotourism. The satisfaction factor "nature and culture" and the satisfaction factor "services" are the ones that greatly influence the intentions to recommend and the intentions to say positive things about the destination, while the satisfaction factors "nature and culture" and "infrastructure" are the ones that considerably influence the return of tourists. Moreover, the satisfaction factor "nature and culture" is the main predictor in the loyalty of tourists; this means that the natural and cultural heritage of the protected areas should be preserved to increase the level of tourists' loyalty to the destination. Moreover, general satisfaction influences return and recommendation intentions and saying positive things about the destination.

Regarding the practical implications, ecotourism companies must plan strategies to improve the conservation and care of the natural and cultural heritage of protected areas. For this, activities that improve the conservation of natural and cultural heritage must be organized. It is necessary to counteract the effects on the natural heritage, take care of natural species, improve compliance with environmental regulations, and reduce pollution and the misuse of natural resources. Likewise, companies must conserve cultural heritage, with an emphasis on maintaining and restoring cultural wealth. In addition, traffic signs, parking lots, infrastructure, and accommodation should be improved; in this way, the level of satisfaction of foreign tourists will be improved. For this, strategies can be implemented that improve the facilities of the accommodation in terms of furnishings and decoration that can give a better comfort to foreign tourists. On the other hand, the service and gastronomy of restaurants, guided tours, and complementary leisure activities can be promoted. For this, the quality of food, furniture, and equipment in restaurants can be improved, which can provide a better experience for tourists through better quality food and a more comfortable and pleasant establishment, notably improving the service and consequently the satisfaction of foreign tourists. Likewise, service trainings can be implemented for guides, which improve the expectations of tourists in relation to environmental and cultural information and education.

Finally, a limitation of this work is the timing of the information gathering, because the demand may vary. Further research should focus on the relationship between satisfaction and the sustainable economic impact in protected areas.

Author Contributions: Conceptualization, M.C.-F., W.C.-F., A.P.-O., A.G.V.-P. and O.C.-F.; methodology, M.C.-F. and W.C.-F.; software, M.C.-F. and O.C.-F.; validation, M.C.-F., W.C.-F., A.P.-O., A.G.V.-P. and O.C.-F.; formal analysis, M.C.-F., W.C.-F. and A.P.-O.; investigation, M.C.-F., W.C.-F., A.P.-O., A.G.V.-P. and O.C.-F.; resources, M.C.-F., W.C.-F., A.P.-O., A.G.V.-P. and O.C.-F.; data curation, M.C.-F.; writing-original draft preparation, M.C.-F.; writing—review and editing, M.C.-F., W.C.-F., A.P.-O., A.G.V.-P. and O.C.-F.; visualization, M.C.-F. and W.C.-F.; supervision, M.C.-F., A.P.-O. and A.G.V.P.; project administration, M.C.-F., A.P.-O. and A.G.V.-P.; All authors have read and agreed to the published version of the manuscript.

Funding: This research received no external funding.

Institutional Review Board Statement: Not applicable.

Informed Consent Statement: Not applicable.

Data Availability Statement: Not applicable.

Conflicts of Interest: The authors declare no conflict of interest. 


\section{References}

1. Hwang, S.N.; Lee, C.; Chen, H.J. The relationship among tourists' involvement, place attachment and interpretation satisfaction in Taiwan's national parks. Tour. Manag. 2005, 26, 143-156. [CrossRef]

2. Ramkissoon, H.; Smith, L.D.G.; Weiler, B. Testing the dimensionality of place attachment and its relationships with place satisfaction and pro-environmental behaviours: A structural equation modelling approach. Tour. Manag. 2013, 36, 552-566. [CrossRef]

3. Borrie, W.T.; Birzell, R.M. Approaches to measuring quality of the wilderness experience. In Proceedings of the Visitor Use Density and Wilderness Experience: Proceedings, Missoula, MT, USA, 13 June 2000; pp. 29-38, RMRS-P-20. Available online: https://winapps.umt.edu/winapps/media2/leopold/pubs/876.pdf (accessed on 6 January 2022).

4. Hornback, K.E.; Eagles, P.F. Guidelines for Public Use Measurement and Reporting at Parks and Protected Areas; IUCN: Fontainebleau, France, 1999.

5. Tonge, J.; Moore, S.A. Importance-satisfaction analysis for marine-park hinterlands: A Western Australian case study. Tour. Manag. 2007, 28, 768-776. [CrossRef]

6. Buckley, R. Eco-Tourism: Principles and Practices; CABI: Wallingford, UK, 2009.

7. Butler, R.; Boyd, S. Tourism and National Parks: Issues and Implications; Wiley: Chichester, UK, 2000.

8. Lawton, L.J. Public protected areas. In The Encyclopedia of Ecotourism; Bond University: Gold Coast, Australia, 2001; pp. 287-302.

9. Weaver, D. Eco-Tourism, 2nd ed.; Milton, Brisbane, Queensland, Australia: Milton, Australia, 2008.

10. Prayag, G.; Hosany, S.; Odeh, K. The role of tourists' emotional experiences and satisfaction in understanding behavioral intentions. J. Dest. Mark. Manag. 2013, 2, 118-127. [CrossRef]

11. Dowling, R.K. Book Review: Critical Issues in Ecotourism: Understanding a Complex Tourism Phenomenon, Edited by James Higham. Int. J. Tour. Policy 2007, 1, 286. [CrossRef]

12. Tao, T.C.; Wall, G. Tourism as a sustainable livelihood strategy. Tour. Manag. 2009, 30, 90-98. [CrossRef]

13. Cheng, T.-M.; Wu, H. How do environmental knowledge, environmental sensitivity, and place attachment affect environmentally responsible behavior? An integrated approach for sustainable island tourism. J. Sustain. Tour. 2015, 23, 557-576. [CrossRef]

14. Carvache-Franco, M.; Carvache-Franco, O.; Carvache-Franco, W.; Villagómez-Buele, C.; Saltos-Layana, A. Sociodemographic aspects and their relationship with the ecotourists'motivations in a coastal national park from Ecuador. Geoj. Tour. Geosites. 2020, 31, 1075-1082. [CrossRef]

15. Fletcher, D.; Fletcher, H. Manageable Predictors of Park Visitor Satisfaction: Maintenance and Personnel. J. Park Recreat. Admi. 2003, 21, 21-37.

16. Blamey, R. Principles of Ecotourism. In The Encyclopedia of Ecotourism; Weaver, D.B., Ed.; CABI Publishing: Wallingford, UK, 2001.

17. Curtin, S. Whale-watching in Kaikoura: Sustainable destination development? J. Ecotourism. 2003, 2, 173-195. [CrossRef]

18. Hvenegaard, G.T. Using tourist typologies for ecotourism research. J. Ecotourism. 2002, 1, 7-18. [CrossRef]

19. Castellanos-Verdugo, M.; Vega-Vázquez, M.; Oviedo-García, M.Á.; Orgaz-Agüera, F. The relevance of psychological factors in the ecotourist experience satisfaction through ecotourist site perceived value. J. Clean. Prod. 2016, 124, 226-235. [CrossRef]

20. Rahman, M.K.; Masud, M.M.; Akhtar, R.; Hossain, M.M. Impact of community participation on sustainable development of marine protected areas: Assessment of ecotourism development. Int. J. Tour. Res. 2021. [CrossRef]

21. World Tourism Organization UNWTO. Glossary of Tourism Terms. 2021. Available online: https://www.unwto.org/es/glosarioterminos-turisticos (accessed on 20 November 2021).

22. Castellano, R.; Chelli, F.M.; Ciommi, M.; Musella, G.; Punzo, G.; Salvati, L. Trahit sua quemque voluptas. The multidimensional satisfaction of foreign tourists visiting Italy. Socio-Econ. Plan. Sci. 2020, 70, 100722. [CrossRef]

23. Tiwari, A.K.; Dash, A.K.; Narayanan, B.G. Foreign tourist arrivals in India from major source countries: An empirical analysis. Curr. Issues Tour. 2018, 21, 1137-1156. [CrossRef]

24. López-Sanz, J.M.; Penelas-Leguía, A.; Gutiérrez-Rodríguez, P.; Cuesta-Valiño, P. Rural Tourism and the Sustainable Development Goals: A Study of the Variables That Most Influence the Behavior of the Tourist. Front. Psychol. 2021, 12, 2949. [CrossRef]

25. Henche, B.G.; Salvaj, E.; Cuesta-Valiño, P. A Sustainable Management Model for Cultural Creative Tourism Ecosystems. Sustainability 2020, 12, 9554. [CrossRef]

26. López-Sanz, J.M.; Penelas-Leguía, A.; Gutiérrez-Rodríguez, P.; Cuesta-Valiño, P. Sustainable Development and Consumer Behavior in Rural Tourism-The Importance of Image and Loyalty for Host Communities. Sustainability 2021, 13, 4763. [CrossRef]

27. López-Sanz, J.M.; Penelas-Leguía, A.; Gutiérrez-Rodríguez, P.; Cuesta-Valiño, P. Sustainable Development and Rural Tourism in Depopulated Areas. Land 2021, 10, 985. [CrossRef]

28. Beard, J.G.; Ragheb, M.G. Measuring leisure satisfaction. J. Leis. Res. 1980, 12, 20-33. [CrossRef]

29. Žabkar, V.; Brenčič, M.M.; Dmitrović, T. Modelling perceived quality, visitor satisfaction and behavioural intentions at the destination level. Tour. Manag. 2010, 31, 537-546. [CrossRef]

30. Bosque, I.R.; San Martín, H. Tourist satisfaction a cognitive-affective model. Ann. Tour. Res. 2008, 35, 551-573. [CrossRef]

31. Ryan, C. From the psychometrics of SERVQUAL to sex: Measurements of tourist satisfaction. In Consumer Behavior in Travel and Tourism; Taylor \& Francis Group: Abingdon, UK, 1999; pp. 267-286.

32. Bigné, J.E.; Andreu, L.; Gnoth, J. The theme park experience: An analysis of pleasure, arousal and satisfaction. Tour. Manag. 2005, 26, 833-844. [CrossRef] 
33. Emir, O.; Kozak, M. Perceived importance of attributes on hotel guests' repeat visit intentions. Turiz. Medunarodni Znan. Stručni Časopis 2011, 59, 131-143. Available online: https:/ / hrcak.srce.hr/ 71005 (accessed on 20 November 2021).

34. Marcussen, C.H. Determinants of tourist spending in cross-sectional studies and at Danish destinations. Tour. Econo. 2011, 17, 833-855. [CrossRef]

35. Devesa, M.; Laguna, M.; Palacios, A. The role of motivation in visitor satisfaction: Empirical evidence in rural tourism. Tour. Manag. 2010, 31, 547-552. [CrossRef]

36. Sun, X.; Chi, C.G.Q.; Xu, H. Developing destination loyalty: The case of Hainan Island. Ann. Tour. Res. 2013, 43, 547-577. [CrossRef]

37. Yoon, Y.S.; Lee, J.S.; Lee, C.K. Measuring festival quality and value affecting visitors' satisfaction and loyalty using a structural approach. Int. J. Hosp. Manag. 2010, 29, 335-342. [CrossRef]

38. Chi, C.G.; Qu, H. Examining structural relationship of destination image, tourist satisfaction and destination loyalty: An integrated approach. Tour. Manag. 2008, 29, 624-636. [CrossRef]

39. Prayag, G.; Ryan, C. Antecedents of tourists' loyalty to Mauritius: The role and influence of destination image, place attachment, personal involvement, and satisfaction. J. Travel Res. 2012, 51, 342-356. [CrossRef]

40. Geva, A.; Goldman, A. Satisfaction measurement in guided tours. Ann. Tour. Res. 1991, 18, 177-185. [CrossRef]

41. Yuksel, A. Managing customer satisfaction and retention: A case of tourist destinations, Turkey. J. Vacat. Mark. 2001, 7, 153-168. [CrossRef]

42. Rittichainuwat, B.N.; Qu, H.; Mongknonvanit, C. A study of the impactof travel satisfaction on the likelihood of travelers to revisit Thailand. J. Travel Tour. Mark. 2002, 12, 19-43. [CrossRef]

43. Tian-Cole, S.; Crompton, J.L.; Willson, V.L. An empirical investigation of the relationships between service quality, satisfaction and behavioral intentions among visitors to a wildlife refuge. J. Leis. Res. 2002, 34, 1-24. [CrossRef]

44. Baker, D.A.; Crompton, J.L. Quality, satisfaction and behavioral intentions. Ann. Tour. Res. 2000, 27, 785-804. [CrossRef]

45. Tonge, J.; Moore, S.A.; Taplin, R. Visitor satisfaction analysis as a tool for park managers: A review and case study. Ann. Leis. Res. 2011, 14, 289-303. [CrossRef]

46. Chen, C.F.; Tsai, D. How destination image and evaluative factors affect behavioral intentions? Tour. Manag. 2007, $28,1115-1122$. [CrossRef]

47. Dharmaratne, G.S.; Yee Sang, F.; Walling, L.J. Tourism potentials for financing protected areas. Ann. Tour. Res. 2000, 27, 590-610. [CrossRef]

48. Sivalıoğlu, P.; Berköz, L. Perceptual evaluation of the national park users. Procedia Soc. Behav. Sci. 2012, 50, 928-940. [CrossRef]

49. Anderson, E.W.; Sullivan, M.W. Customer satisfaction and retention across firms. In TIMS College of Marketing Special Interest Conference on Service Marketing, Nashville, TN, September; Zeithaml, V.A., Berry, L.L., Parasuraman, A., Eds.; TIMS College of Marketing: Nashville, TN, USA, 1990; Available online: https:/ /scholar.google.com/citations?view_op=view_citation\&hl=zhTW\&user=W4k4QrMAAAAJ\&citation_for_view=W4k4QrMAAAAJ:ufrVoPGSRksC (accessed on 9 January 2022).

50. Cronin, J.J., Jr.; Taylor, S.A. Measuring service quality: A reexamination and extension. J. Mark. 1992, 56, 55-68. [CrossRef]

51. Fornell, C. A national customer satisfaction barometer: The Swedish experience. J. Mark. 1992, 56, 6-21. [CrossRef]

52. Keaveney, S.M. Customer switching behavior in service industries: An exploratory study. J. Mark. 1995, 59, 71-82. [CrossRef]

53. Oliver, R.L. A cognitive model of the antecedents and consequences of satisfaction decisions. J. Mark. Res. 1980, 17, 460-469. [CrossRef]

54. Oliver, R.L.; Swan, J.E. Consumer perceptions of interpersonal equity and satisfaction in transactions: A field survey approach J. Mark. 1989, 53, 21-35. [CrossRef]

55. Alegre, J.; Cladera, M. Repeat visitation in mature sun and sand holiday destinations. J. Travel Res. 2006, 44, 288-297. [CrossRef]

56. Caneen, J.M. Cultural determinants of tourist intention to return. Tour. Anal. 2003, 8, 237-242. [CrossRef]

57. Kozak, M. Repeaters' behavior at two distinct destinations. Ann. Tour. Res. 2001, 28, 784-807. [CrossRef]

58. Kozak, M.; Rimmington, M. Tourist satisfaction with Mallorca, Spain, as an off-season holiday destination. J. Travel Res. 2000, 38, 260-269. [CrossRef]

59. Petrick, J.F. Are loyal visitors desired visitors? Tour. Manag. 2004, 25, 463-470. [CrossRef]

60. Pritchard, M.P. The attitudinal and behavioral consequences of destination performance. Tour. Anal. 2003, 8, 61-73. [CrossRef]

61. Um, S.; Chon, K.; Ro, Y. Antecedents of revisit intention. Ann. Tour. Res. 2006, 33, 1141-1158. [CrossRef]

62. Yoon, Y.; Uysal, M. An examination of the effects of motivation and satisfaction on destination loyalty: A structural model. Tour. Manag. 2005, 26, 45-56. [CrossRef]

63. Carvache-Franco, M.; Alvarez-Risco, A.; Carvache-Franco, O.; Carvache-Franco, W.; Estrada-Merino, A.; Villalobos-Alvarez, D Perceived value and its influence on satisfaction and loyalty in a coastal city: A study from Lima, Peru. J. Policy Res. Tour. Leis. 2021, 1-16. [CrossRef]

64. Tsiotsou, R.; Vasioti, E. Using demographics and leisure activities to predict satisfaction with tourism services in Greece. J. Hosp. Leis. Mark. 2006, 14, 69-82. [CrossRef]

65. Meng, F.; Tepanon, Y.; Uysal, M. Measuring tourist satisfaction by attribute and motivation: The case of a nature-based resort. J. Vacat. Mark. 2008, 14, 41-56. [CrossRef]

66. Lee, C.F. Tourist satisfaction with forest recreation experience: A segment-based approach. Anatolia 2015, 26, 535-548. [CrossRef] 
67. Adam, I.; Adongo, C.A.; Amuquandoh, F.E. A structural decompositional analysis of eco-visitors' motivations, satisfaction and post-purchase behaviour. J. Ecotourism. 2019, 18, 60-81. [CrossRef]

68. Chen, F.; Liu, J.; Wu, J.; Sjafrie, N.D.M.; Rahmadi, P.; Putranto, R.Y. Measuring the relationship among stakeholders from value-satisfaction-demand in the development of ecotourism of Marine Park. Mar. Policy 2021, 129, 104519. [CrossRef]

69. Xu, L.; Ao, C.; Liu, B.; Cai, Z. Exploring the Influence of Multidimensional Tourist Satisfaction on Preferences for Wetland Ecotourism: A Case Study in Zhalong National Nature Reserve, China. Wetlands 2021, 41, 1-16. [CrossRef]

70. Chan, W.C.; Wan Ibrahim, W.H.; Lo, M.C.; Mohamad, A.A.; Ramayah, T.; Chin, C.H. Controllable drivers that influence tourists' satisfaction and revisit intention to Semenggoh Nature Reserve: The moderating impact of destination image. J. Ecotourism. 2021, 1-19. [CrossRef]

71. Hwang, K.; Lee, J. Antecedents and consequences of ecotourism behavior: Independent and interdependent self-construals, ecological belief, willingness to pay for ecotourism services and satisfaction with life. Sustainability 2018, 10, 789. [CrossRef]

72. Lee, T.H.; Jan, F.H.; Chen, J.C. Influence analysis of interpretation services on ecotourism behavior for wildlife tourists. J. Sustain. Tour. 2021, 1-19. [CrossRef]

73. Li, T.T.; Liu, F.; Soutar, G.N. Experiences, post-trip destination image, satisfaction, and loyalty: A study in an ecotourism context. J. Dest. Mark. Manag. 2021, 19, 100547. [CrossRef]

74. Quynh, N.; Hoai, N.T.; Van Loi, N. The role of emotional experience and destination image on ecotourism satisfaction. Span. J. Mark-ESIC 2021, 25, 312-332. [CrossRef]

75. Crompton, L. Motivations for pleasure vacation. Ann. Tour. 1979, 6, 408-424. [CrossRef]

76. Fodness, D. Measuring tourist motivation. Ann. Tour. Res. 1994, 21, 555-581. [CrossRef]

77. Weaver, D.B.; Lawton, L.J. Overnight ecotourist market segmentation in the Gold Coast hinterland of Australia. J. Travel Res. 2002, 40, 270-280. [CrossRef]

78. McGehee, N.G.; Kim, K. Motivation for agri-tourism entrepreneurship. J. Travel Res. 2004, 43, 161-170. [CrossRef]

79. Jang, S.S.; Wu, C.M.E. Seniors' travel motivation and the influential factors: An examination of Taiwanese seniors. Tour. Manag. 2006, 27, 306-316. [CrossRef]

80. Lee, S.; Lee, S.; Lee, G. Ecotourists' motivation and revisit intention: A case study of restored ecological parks in South Korea. Asia Pac. J. Tour. Res. 2014, 19, 1327-1344. [CrossRef]

81. Formica, S.; Uysal, M. Market segmentation of an international cultural-historical event in Italy. J. Travel Res. 1998, 36, 16-24. [CrossRef]

82. Kastenholz, E.; Davis, D.; Paul, G. Segmenting tourism in rural areas: The case of North and Central Portugal. J. Travel Res. 1999, 37, 353-363. [CrossRef]

83. Johns, N.; Gyimothy, S. Market segmentation and the prediction of tourist behavior: The case of Bornholm, Denmark. J. Travel Res. 2002, 40, 316-327. [CrossRef]

84. Tolvanen, A.; Kangas, K.; Tarvainen, O.; Huhta, E.; Jäkäläniemi, A.; Kyttä, M.; Tyrväinen, L. Data on recreational activities, respondents' values, land use preferences, protection level and biodiversity in nature-based tourism areas in Finland. Data Brief. 2020, 31, 105724. [CrossRef] [PubMed]

85. He, M.; Li, J.; Li, J.; Chen, H. A comparative study on the effect of soundscape and landscape on tourism experience Int. J. Tour. Res. 2019, 21, 11-22. [CrossRef]

86. Hair, J.F.; Celsi, M.; Ortinau, D.J.; Bush, R.P. Essentials of Marketing Research; McGraw-Hill/Irwin: New York, NY, USA, 2010.

87. Carvache-Franco, M.; Carvache-Franco, W.; Carvache-Franco, O.; Hernández-Lara, A.B.; Buele, C.V. Segmentation, motivation, and sociodemographic aspects of tourist demand in a coastal marine destination: A case study in Manta (Ecuador). Curr. Issues Tour. 2020, 23, 1234-1247. [CrossRef]

88. Jang, S.S.; Feng, R. Temporal destination revisit intention: The effects of novelty seeking and satisfaction. Tour. Manag. 2007, 28, 580-590. [CrossRef] 